\title{
APPLICATION OF COLOR DOPPLER ULTRASOUND IN MONITORING THE EFFECT OF REDUCING THE TRANSJUGULAR PORTOSYSTEM SHUNT DUE TO HEPATIC ENCEPHALOPATHY: CASE REPORT
}

\author{
Dragan Dulovic, Sinisa Rusovic, Miodrag Mihajlovic, Igor Sekulic, Srdjan Prodanovic \\ Institute of Radiology, Military Medical Academy, Belgrade, Serbia
}

\section{PRIMENA COLOR DOPPLER ULTRAZVUKA U PRAĆENJU EFEKTA REDUKCIJE TRANSJUGULARNOG PORTOSISTEMSKOG ŠANTA ZBOG HEPATIČNE ENCEFALOPATIJE: PRIKAZ SLUČAJA}

\author{
Dragan Dulović, Siniša Rusović, Miodrag Mihajlović, Igor Sekulić, Srđan Prodanović \\ Institut za radiologiju, Vojnomedicinska akademija, Beograd, Srbija
}

\begin{abstract}
Transjugular portosystemic shunt (TIPS) is an interventional vascular radiology procedure, which represents a method of choice for reducing problems of patients with portent hypertension. However, in a number of patients a late complication hepatic encephalopathy (HE) may occur, thus in that situation the reduction of lumen trough shunt's flow is needed. In such patient cases, we can determine, with Color Doppler ultrasound (CDU), the flow through shunt before and after the reduction of lumen. In this article a case of patient is presented, where after the use of TIPS, the hepatic encephalopathy occurred and after the reduction of lumen was conducted. The effects of this procedure were followed with Color Doppler ultrasound. Conclusion: CDU as a simple and non-invasive method, with high rate of specifics and sensitivity, represents an adequate radiology method, which can be used for monitoring conditions of patients with TIPS, or more precisely, for monitoring the effects of reduction of shunt's lumen.
\end{abstract}

Key words: portasystemic shunt, transjugular Intrahepatic; hepatic encephalopathy; ultrasonography; Doppler, color.

\section{INTRODUCTION}

TIPS represents the method of choice for reduction of problems, in cases of patients with portent hypertension, caused as a result of increased vascular resistance at the liver level, most often on the field of cirrhosis. TIPS is iatrogenic shunt, a channel that is connecting vein port (VP) with systemic blood flow, which allows the bloodstream to bypass the liver. It is implanted by interventional radiologists, percutaneously through the jugular vein. An endovascular pathway leads to the lower hollow vein from the jugular vein, through the brachiocephalic and upper hollow vein. It enters the central hepatic vein (CHV). By placing the stent through the hepatic parenchyma, between the CHV and the VP, a porto-system shunt is formed. The complications that this procedure carries are divided according to the time of appearance into intraprocedural, followed by those that

\section{SAZ̆ETAK}

Transjugularni portosistemski šant (TIPS) jeste procedura interventne vaskularne radiologije koja predstavlja metodu izbora za smanjenje tegoba kod pacijenata s portnom hipertenzijom. Međutim, kod jednog broja pacijenata kao kasna komplikacija javlja se hepatična encefalopatija (HE), te je neophodno smanjiti protok kroz šant redukcijom lumena. Kod ovakvih bolesnika Color Doppler ultrazvukom (CDUZ) možemo utvrditi protok kroz šant, pre redukcije lumena $i$ nakon nje. Prikazana je pacijentkinja kod koje se nakon plasiranja TIPS-a javila HE $i$ kod koje je izvršeno redukovanje lumena. Efekti procedure praćeni su CDUZ-om. CDUZ kao jednostavna i neinvazivna metoda, s visokom stopom specifičnosti $i$ senzitivnosti, adekvatna je radiološka metoda kojom se mogu pratiti bolesnici s TIPS-om, odnosno efekti redukcije lumena šanta.

Ključne reči: portosistemski šant, transjugularni intrahepatični; hepatična encefalopatija; ultrazvuk, Dopler, kolor.

occur immediately after the intervention and late and the ones which occur after a month. Late complications include abnormalities of stent and HE (1). The hepatic encephalopathy in case of certain patients need to be taken care of by reducing the flow through the shunt. Hence in those cases it is necessary to determine the flow before and after the reduction of lumens decrease, in order to adequately monitor the effects of reduction. For this purpose, a CDU can be used as a precise and safe method. We present a patient who after the implantation of TIPS developed $\mathrm{HE}$ as a late complication, and therefore a flow reduction in the shunt was carried out, and the flow was followed by the CDU.

\section{CASE REPORT}

The case describes the adult woman who had hepatic encephalopathy after the use of TIPS. The finding of ultrasound color Doppler are presented in the figure 1, tables A, B, C. 

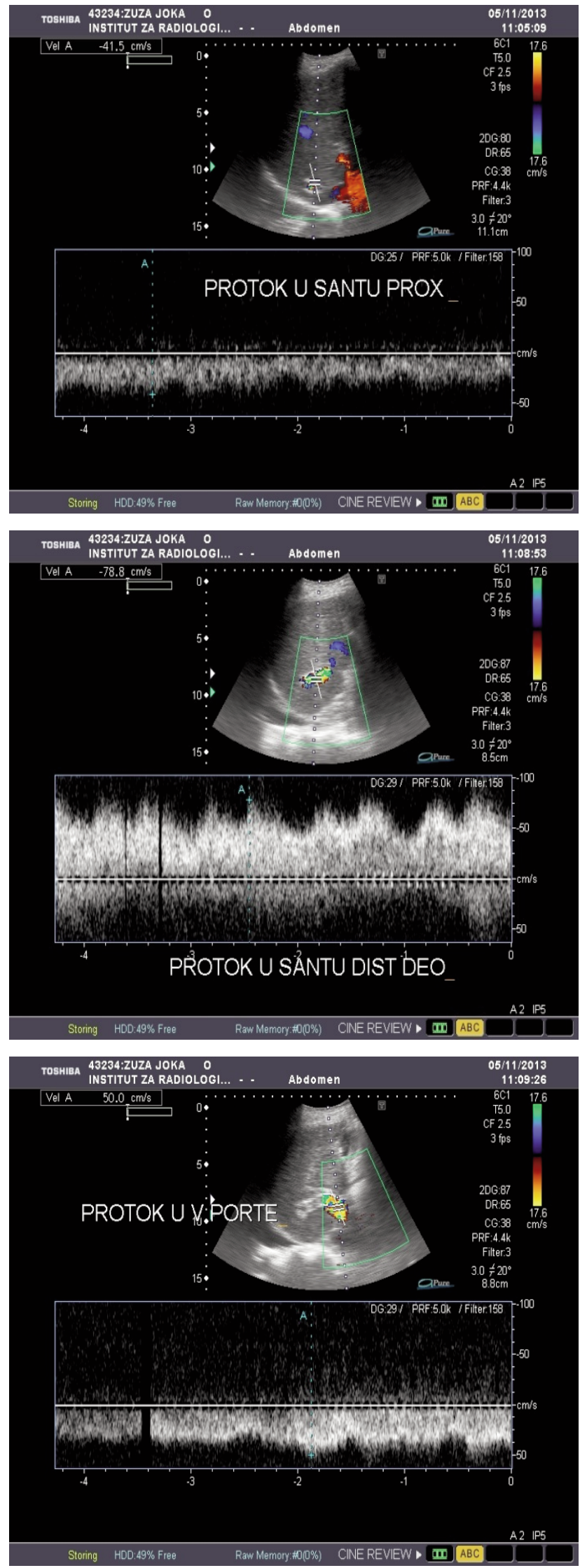

Figure 1. Vein port flow before procedure.

\section{DISCUSSION}

HE is a complex pathological entity connected with both liver dysfunction and portosystemic shunt. On one hand, patients with acute hepatic insufficiency may develop HE, although there is no port-system (PS) shunt, while patients with PS shunt, whether pathologic or iatrogenic, may develop $\mathrm{HE}$, regardless the liver is not in an insufficient condition. HE occurs as a result of liver circumvention as a filter that reduces the concentration of nitrogenous substances absorbed from the gastrointestinal tract (2).

In the last two decades, in which the TIPS was used, several respectable studies that consider the problem of HE in TIPS have been conducted. In one extensive, retrospective study, involving 254 patients, the $\mathrm{HE}$ incidence ranged up to $34 \%$ (86 patients), and it was successfully regulated by a medication-dietary approach in almost all patients, therefore the flow reduction in TIPS was necessary in just 2 cases. It has also been shown that the incidence of HE is higher in elderly patients (2). The incidence of HE may be associated with renal function as well as with HE episodes prior to placement of TIPS (3).

Reduction of the lumen shunt, and thus the flow through the shunt itself, is possible with an expanding stent of the sandstone shape or the corresponding stent graft (4). However, it has been shown that shunt reduction, which prevents the occurrence of $\mathrm{HE}$, increases the incidence of recurrent hepatic hydrotaxis $(\mathrm{HH})$ and hepatic ascites (HA), and therefore it is necessary to find a measure to achieve $\mathrm{HH}$ and HA prevention and to also reduce HE incidence. It turned out that this balance is best achieved by the shunt that reduces the flow in the portal vein by $40-50 \%(5)$, and that a better result is achieved by using a stent of an inner diameter of $8 \mathrm{~mm}$, rather than a stent of $10 \mathrm{~mm}(6)$.

The aim of our presentation is to demonstrate the ability to monitor patients in whom the reduction of TIPS has been made, with CDU as available and a relatively simple method, safe and above all a method that is characterized by a high degree of sensitivity and specificity.

The characteristics of the spectral flow-through-stent analysis in TIPS are monophasic, uniform and mild pulsatile flow. It is optimally that the maximal systolic velocity (PSV) ranges in the range of $90-120 \mathrm{~cm} / \mathrm{s}$ and tolerances up to $50-60 \mathrm{~cm} / \mathrm{s}$. If the PSV is below $50 \mathrm{~cm} / \mathrm{s}$, this indicates that there is stenosis of the stent in its entire length and that occlusion will eventually occur. On the other hand, if segmental stenosis occurs, at the site of narrowing, speeds up to $4 \mathrm{~m} / \mathrm{s}$ are registered (7).

With the patient shown, the PSV values before the reduction ranged from $40-79 \mathrm{~cm} / \mathrm{s}$ (proximal and distal) to the shunt and vein port about $50 \mathrm{~cm} / \mathrm{s}$ (Figure 1). After the procedure for reducing the lumen shunt, the shaft flows ranged from $48-123 \mathrm{~cm} / \mathrm{s}$, and in vein port about $24 \mathrm{~cm} / \mathrm{s}$. (Figure 2) 

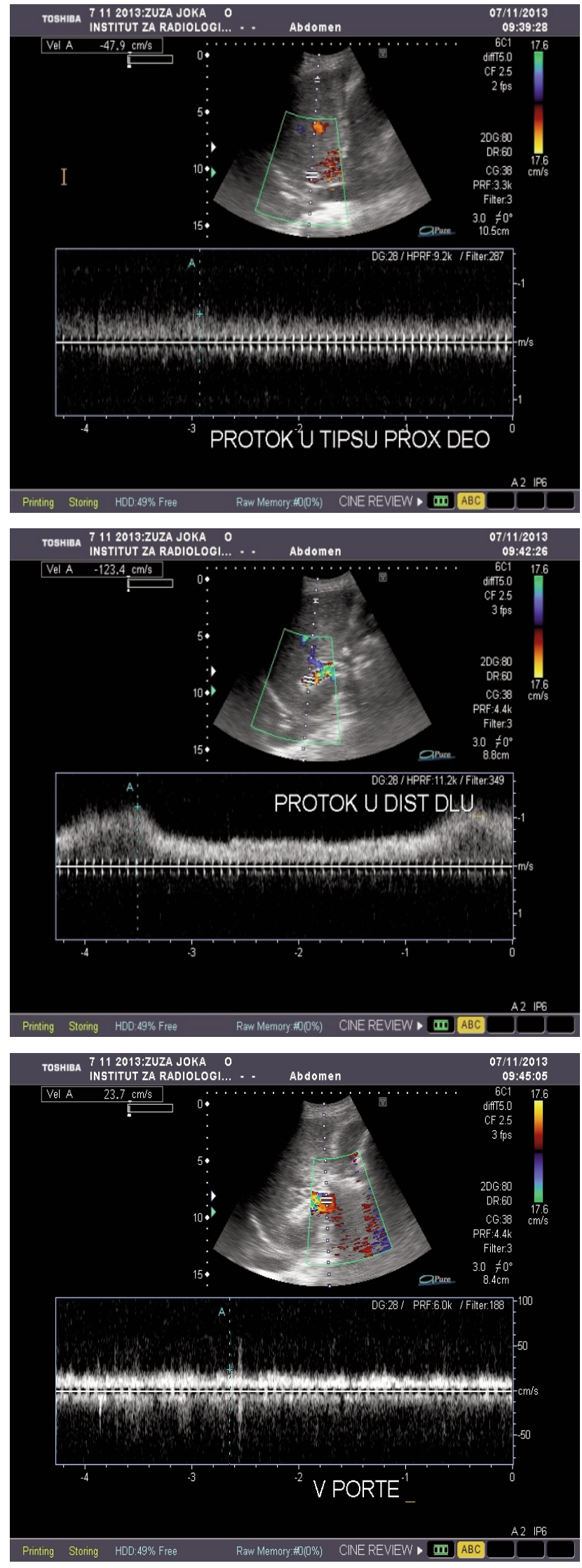

Figure 2. Vein port flow after procedure.

\section{CONCLUSION}

CDU provides adequate control of passibility of the stent placed in TIPS, as well as the monitoring of stent flow before and after the lumen reduction, which is shown in the presented case.

\section{ABBREVIATION}

TIPS - Transjugular portosystemic shunt

$\mathrm{HE}$ - hepatic encephalopathy

CDU - color doppler ultrasound

CDUZ - kolor dopler ultrazvuk

$\mathrm{VP}$ - vein port

$\mathrm{CHV}$ - central hepatic vein

PS - port-system

$\mathrm{HA}$ - hepatic ascites

$\mathrm{HH}$ - hepatic hydrotaxis

PSV - peak systolic velocity

\section{REFERENCES}

1. Qin JP, Jiang MD, Tang W, et al. Clinical effects and complications of TIPS for portal hypertension due to cirrhosis: a single center. World J Gastroenterol 2013; 19: 8085-92.

2. Casadaban LC, Parvinian A, Minocha J, et al. Clearing the confusion over hepatic encephalopathy after TIPS creation: Incidence, Prognostic Factors, and Clinical Outcomes. Dig Dis Sci 2015; 60: 1059-66.

3. Rössle M, Gerbes AL. TIPS for the treatment of refractory ascites, hepatorenal syndrome and hepatic hydrothorax: a critical update. Gut 2010; 59: 9881000 .

4. Colombato L. The role of transjugular intrahepatic portosystemic shunt (TIPS) in the management of portal hypertension. J Clin Gastroenterol 2007; 41: S344-51.

5. Krishnamoorthy TL, Taneja M, Chang PE. Symptomatic hepatic hydrothorax successfully treated with transjugular intrahepatic portosystemic shunt (TIPS)-role of titration of portosystemic gradient reduction to avoid post-TIPS encephalopathy. Clin Case Rep 2014; 2: 93-7.

6. Qin JP, Jiang MD, Tang W, et al. Clinical effects and complications of TIPS for portal hypertension due to cirrhosis: a single center. World J Gastroenterol 2013; 19: 8085-92.

7. Brkljačić B. Dopler krvnih žila. Zagreb: Medicinska naklada, 2000. 